\title{
Promotion of Foxtail Millet for Food Security through Front Line Demonstration
}

\author{
S. Vanishree ${ }^{*}$, G.N. Maraddi ${ }^{2}$ and Aravind Rathod ${ }^{3}$ \\ ${ }^{1}$ Department of Home Science, ${ }^{2}$ Department of Agriculture Extension, Agriculture Extension \\ Education Centre, Lingasugur, UAS Raichur, Karnataka, India \\ ${ }^{3}$ SMS Horticulture, Agriculture Extension Education Centre, Lingasugur, UAS Raichur, \\ Karnataka, India \\ *Corresponding author
}

\section{A B S T R A C T}

\begin{tabular}{|l|}
\hline K e y w o r d s \\
$\begin{array}{l}\text { Millets, Variety, Value } \\
\text { addition, Capacity } \\
\text { building, Processing }\end{array}$ \\
\hline Article Info \\
\hline $\begin{array}{l}\text { Accepted: } \\
\text { 22 July } 2018 \\
\text { Available Online: } \\
\text { 10 August } 2018\end{array}$ \\
\hline
\end{tabular}

A study was conducted during 2017-18 under the jurisdiction of Agricultural Extension Education Centre Lingasugur, University of Agricultural Sciences, Raichur. The purpose was to promote growing and consumption of foxtail millet to achieve the food security through Front Line Demonstration and by capacity building program. The problems in adopting foxtail millet crops were also analyzed through pre structured schedule. Foxtail millet seeds (HMT 100-1) were distributed to randomly selected beneficiaries under NFSM (National Food Security Mission). Results revealed that the improved variety HMT 100-1 gave higher yield (5.33qtls/acre) compared to farmer's local variety (4.13qtls/acre). Lack of processing industries, marketing and availability of high yielding varieties were the major problems as expressed by the farmers in adopting foxtail millet. To enhance the consumption, foxtail millet based recipes were demonstrated in capacity building programmes. Among the value added millet products, Foxtail millet papad scored higher mean value followed by plain rice and bisebele bath.

\section{Introduction}

Millets are the future crops of India. They include number of small grained cereals. Based on grain size, millets have been classified as major millets (Sorghum and Pearl millet) and minor millets (Finger millet, foxtail, kodo, proso, barnyard and little millet). Foxtail millet (Setaria italic L) is an important food grain crop of the semi-arid tropics in India. It is drought tolerant crop cultivated mainly for food grain and fodder for livestock. Grains are highly nutritious with good amount of dietary fibre, phytochemicals, vitamins and lower glycemic index.

Foxtail grain contains $10-12 \%$ protein, $4.7 \%$ fat, $60.6 \%$ carbohydrates, $2.29 \% \quad-2.7 \%$ Lysine and $0.59 \mathrm{mg}$ Thiamine (Chapke et al., 2018) the present study was undertaken with a view to promote growing and consumption of 
millets thereby achieving food security by introducing High Yielding Variety HMT 1001 .

\section{Materials and Methods}

Present study was conducted in Lingasugur taluk of Raichur district, Karnataka. Thirty farmers were selected randomly from three villages (Adavibavi, Basapura and Buddinni) based on their interest and HMT 100-1 seeds were distributed under NFSM-coarse cereals (National Food Security Mission).

A pre structured schedule was administered to collect the information on problems encountered in adopting foxtail millet crop, processing and adopting millet as a source of daily food. Capacity building programmes were organized to enhance their knowledge on nutritional and health aspects of millets and their utilization in regular diet. Different value added products were demonstrated to the selected beneficiaries and their acceptance was evaluated by Weighted Mean Score.

\section{Results and Discussion}

It is observed from the table 1 that lack of millet processing industries $(100 \%)$ in their area was the major problem expressed by farmers followed by marketing problem (26.00\%), availability of High Yielding Varieties (25.00\%), lower economic returns
(24.00\%) and lack of acceptance as regular food $(76.66 \%)$. Incorporation of millets in the conventionally used refined wheat flour can improve nutritional quality (Shrestha and Srivastava, 2015).

The major factor discouraging its cultivation and consumption with improvement in living standard or urbanization is the drudgery associated with its processing as stated in the study conducted by Vanithasri and Kanchana, 2013.

In addition, a combination of factors like low remuneration as compared to other food crop, lack of input subsidies and price incentives, subsidized supply of fine cereals through public Distribution System (PDS) and change in consumer preference (difficulty in processing, low shelf life of flour and low social status attached to millets) have led to shift from production of millets to other competing crops were also the problems as narrated by Pthak (2013).

Performance of improved variety HMT 100-1 was better compared to local variety in all the demonstration plots as observed in table 2 . About 25 per cent of increase in yield was observed. Thus introduction of High Yielding Varieties proved to increase yield, which in turn increases economic returns. Similar results narrated by Kammar and Vanishree (2017).

Table.1 Problems identified in growing of millets by farmers $\mathrm{N}=30$

\begin{tabular}{|c|l|c|}
\hline No & \multicolumn{1}{|c|}{ Problems } & \% \\
\hline 1 & Non-availability of High Yielding Varieties & $25(83.33)$ \\
\hline 2 & Lack of millet processing industries & $30(100)$ \\
\hline 3 & Problem in marketing of millets & $29(96.66)$ \\
\hline 4 & Lack of knowledge about health benefits & $26(86.66)$ \\
\hline 5 & Lack of acceptance as regular food & $23(76.66)$ \\
\hline 6 & Lower economic returns & $24(80.00)$ \\
\hline
\end{tabular}


Table.2 Performance of HMT-100-1 over local varieties

\begin{tabular}{|c|c|c|c|c|}
\hline \multirow{2}{*}{$\begin{array}{c}\text { Name of the } \\
\text { village }\end{array}$} & \multirow{2}{*}{$\begin{array}{l}\text { Number of } \\
\text { beneficiaries }\end{array}$} & \multicolumn{2}{|c|}{ Yield } & \multirow[b]{2}{*}{$\begin{array}{c}\% \text { increase over } \\
\text { local }\end{array}$} \\
\hline & & Local variety & HМТ 100-1 & \\
\hline Muski & 5 & 4.1 & 5.2 & 26.82 \\
\hline Basapura & 10 & 4.0 & 5.0 & 25.00 \\
\hline Buddinni & 15 & 4.3 & 5.4 & 25.58 \\
\hline Total & 30 & 4.13 & 5.33 & 25.80 \\
\hline
\end{tabular}

Table.3 Preference of value added products by beneficiaries

\begin{tabular}{|l|c|c|c|c|}
\hline Recipies & Always & Sometimes & Never & WMS \\
\hline Upama & 16 & 14 & 1 & 2.53 \\
\hline Bisebelebath & 18 & 10 & 2 & 2.53 \\
\hline Roti & 15 & 16 & 9 & 1.86 \\
\hline Rice & 17 & 13 & - & 2.56 \\
\hline Thalipet & 12 & 17 & 1 & 2.36 \\
\hline Papad & 20 & 9 & 1 & 2.63 \\
\hline
\end{tabular}

Among the foxtail millet value added products, papad scored highest mean value (2.63) followed by foxtail rice (2.56) as narrated in table 3. Upama and bisibelebath both scored same mean values (2.53). However less mean value was scored by roti (1.86) which indicates foxtail millet roti was less preferred by the respondents. This indicated that foxtail millet was very much suitable for making papad and rice. In addition, their preference for rice items like bisibelebath and thalipet found to be higher compared to roti, which indicates millets can be used in place of paddy.

Introduction of High Yielding Varieties to farmers can be helpful in adopting millet crops. Demand for millets can be increased by creating awareness regarding their environmental sustainability, nutritional and other health benefits. Measures need to be taken to making them available through Public Distribution System. So that it reach to all categories of population. Further, millet value added products can be included under feeding programmes like mid-day meal and adolescent feeding programmes.

\section{References}

Chapke, R. R., Prabhakar, Shyam Prasad, G., Das, I. K., and Tonapi, V. A., 2018, Improved millets production technologies and their impact. Technology bulletin, ICAR- Indian Institute of Millet Research, Hyderabad, pp-1-5

Kammar, M. R. and Vanishree, S., 2017, Entrepreneurship development promotion through

Millet processing in Raichur district of Karnataka State, India. Plant Archives, 17(2):1460-1462.

Pathak, H. C., 2013, Role of millets in nutritional security of India. Policy paper by NASS, pp-1-4.

Srestha, R. and Srivastava, S., 2015, Functional properties of finger millet and barnyard millet flours and flour 
blend. International Journal of Science and Research, 6(6):775-779.

Vanithasri, J and Kanchana, S., 2013, Studies on quality evaluation of idli prepared from barnyard millet (Echinochola frumentacaea). Asian Journal of Home Science, 3(2):373-378.

\section{How to cite this article:}

Vanishree, S., G.N. Maraddi and Aravind Rathod. 2018. Promotion of Foxtail Millet for Food Security through Front Line Demonstration. Int.J.Curr.Microbiol.App.Sci. 7(08): 4036-4039. doi: https://doi.org/10.20546/ijcmas.2018.708.418 